\title{
GMR
}

\section{Genetic diversity among exotic cotton accessions as for qualitative and quantitative traits}

\author{
L.P. de Carvalho ${ }^{1}$, F.J.C. Farias ${ }^{1}$, J.I.S. Rodrigues ${ }^{1}$, N.D. Suassuna ${ }^{1}$ and \\ P.E. Teodoro ${ }^{2}$ \\ ${ }^{1}$ Centro Nacional de Pesquisa de Algodão, Embrapa Algodão, \\ Campina Grande, PB, Brasil \\ ${ }^{2}$ Departamento de Biologia Geral, Universidade Federal de Viçosa, Viçosa, \\ MG, Brasil \\ Corresponding author: P.E. Teodoro \\ E-mail: eduteodoro@hotmail.com
}

Genet. Mol. Res. 16 (1): gmr16019590

Received December 20, 2016

Accepted January 19, 2017

Published February 8, 2017

DOI http://dx.doi.org/10.4238/gmr16019590

Copyright $(2017$ The Authors. This is an open-access article distributed under the terms of the Creative Commons Attribution ShareAlike (CC BY-SA) 4.0 License.

\begin{abstract}
Studying genetic diversity among a group of genotypes is important in genetic breeding because identifying hybrid combinations of greater heterotic effect also increases the chance of obtaining plants with favorable allele combinations in an intra-population selection program. The objective of this study was to compare different types of long and extra-long staple cotton and their genetic diversity in relation to the fiber traits and some agronomic traits in order to grant breeding programs. Diversity analysis among 29 cotton accessions based on qualitative and quantitative traits and joint including qualitative and quantitative traits was performed. Analysis based on qualitative and quantitative traits and joint met the accessions in three, two, and three groups, respectively. The cross between genotypes Giza 59 and Pima unknown was the most promising to generate segregating populations, comprising simultaneously resistance (based on molecular markers)
\end{abstract}

Genetics and Molecular Research 16 (1): gmr16019590 
to blue disease and bacterial blight, partial resistance to root-knot nematode, smaller size, in addition to good fiber characteristics. These populations can be used in recurrent selection programs as donors of alleles for development of long-staple cotton genotypes.

Key words: Fiber quality, Gossypium sp; Gower distance; Cotton-breeding program

\section{INTRODUCTION}

There are four Gossypium species domesticated for their cotton fibers. Upland cotton (Gossypium hirsutum L.r. latifolium Hutch.) accounts for more than $95 \%$ of global cotton fiber production due its high yield potential and broader environmental adaptation. The other three cultivated species are G. barbadense L., G. arboreum L., and G. herbaceum L. Despite the low fiber productivity, when compared to the upland cotton, the Egyptian or Pima cotton ( $G$. barbadense) has an excellent fiber quality. One of the main goals of a cotton-breeding program is selection of genotypes with higher fiber quality required by the textile industries (Hoogerheide et al., 2007) while maintaining yield potential. The hybridization of G. hirsutum and G. barbadense has been used to attain quality of the fiber with little success (Smith et al., 2008). The changes in weaving technology, competition with synthetic fibers, and the globalization of cotton and textile production have increased the demand for better quality fibers (Smith et al., 2008). Cotton fiber characteristics can vary according to species. Length is one of the most important fiber feature and can be classified as short, medium, long, and extra-long (Farias et al., 2016). Industrial textiles requirements in Brazil is medium fiber (about $28 \mathrm{~mm}$ ) for most cotton applications. In addition to greater length, the textile industry requires good fiber strength, low short fiber index, fibers with more uniformity of length, and with lower micronaire variation amplitude to meet the constant increases in processing speed.

Extra-long staple (ELS) upland cotton in the USA has upper half mean length (UHML) $\geq 32 \mathrm{~mm}$ while extra-long G. barbadense L., such as Pima, Giza, and Tanguis, is referred as ELS cotton, and the shortest category for UHML with this type of cotton was $34.8 \mathrm{~mm}$ in 2007 (Smith et al., 2008). Recently, ELS upland having fiber length of at least $32 \mathrm{~mm}$ has been developed within upland (Morello et al., 2012). Average UHML of cotton produced in Brazil in 2013 was $28 \mathrm{~mm}$, with little long or extra-long fiber cotton production during the last years. For that reason, it is important that breeding programs focus on the selection of these types of cotton to supply the expected future demand.

Knowing the genetic diversity among $G$. barbadense L. genotypes (cultivars used around the world) and G. hirsutum L. with and without introgression of G. barbadense L. is important in cotton breeding for fiber quality, especially to identify genotypes that may contribute to alleles for fiber quality breeding. By knowing these combinations, it is higher the probability of recovering superior genotypes in the segregating generations (Carvalho et al., 2003). The objective of this study was to compare different types of long and extra-long staple cotton and their genetic diversity in relation to the fiber traits and some agronomic characters in order to grant breeding programs.

Genetics and Molecular Research 16 (1): gmr16019590 


\section{MATERIAL AND METHODS}

\section{Conducting the experiment}

Seeds of 29 accessions were grown under nethouse culture at Campina Grande, PB, Brazil, in lines of $5 \mathrm{~m}$ in length, spacing $1 \mathrm{~m}$ and with 20 plants in each row. Opening day of the first flower in each row was recorded, and from this date, the number of days for flowering in relation to the planting date was calculated.

Due to the high size of some accessions, the growth regulator mepiquat chloride (Pix $\mathrm{HC}^{\circledR}$ ) was applied at a dose of $0.05 \mathrm{~mL} / \mathrm{L}$ at 29,43 , and 52 days after planting in all accessions. At harvest, it was collected 20 bolls from each row for fiber analysis in HVI (High Volume Instrument) and measured the height at five plants from each plot. Seed cotton from the samples was ginned on a roller gin and the lint percent was calculated.

\section{Traits evaluated}

Quantitative traits evaluated were: days for the emergence of the first flower, plant height, percentage of fibers, boll weight, length of fibers, fiber uniformity, short fiber index, fiber strength, elongation, micronaire, fiber maturity, reflectance, yellowing degree, and spinning.

For evaluating the qualitative characteristics (disease resistance), three pairs of SSR primers labeled with fluorochrome were used in genotyping (DC20027, CIR246, and BNL 3661). These primers were selected because they are physically linked to genes that confer total resistance to the blue disease caused by Cotton leafroll dwarf virus and bacterial blight caused by Xanthomonas citri subsp malvacearum, and partial resistance to the root-knot nematode (Meloidogyne incognita), respectively. As resistant controls, it was used cotton genotypes Delta Opal (blue disease and bacterial blight) and M315 (root-knot). PCRs were conducted in a multiplex system using the Kit PCR Multiplex (Qiagen) for final volume of 5 $\mu \mathrm{L}$, containing $10 \mathrm{ng}$ DNA, $2.5 \mu \mathrm{L} 2 \mathrm{X}$ Qiagen multiplex PCR Master mix (HotStarTaq DNA Polymerase, PCR amplification buffer, $3 \mathrm{mM} \mathrm{MgCl}_{2}$ ), 0.5 Q-solution, each pair of primer (forward and reverse) in optimized concentrations, and water RNAase free. PCR programming in thermocycler followed the steps: initial denaturation at $95^{\circ} \mathrm{C}$ for $15 \mathrm{~min}$; followed by 34 cycles and each consisting of a denaturation step at $95^{\circ} \mathrm{C}$ for $1 \mathrm{~min}$; one annealing at $55^{\circ} \mathrm{C}$ for $1.5 \mathrm{~min}$. and one extension at $72^{\circ} \mathrm{C}$ for $1 \mathrm{~min}$. At last, $60^{\circ} \mathrm{C}$ for $30 \mathrm{~min}$ of final extension. Then, we prepared a mix containing $0.5 \mu \mathrm{L}$ of this dilution, $0.08 \mu \mathrm{L}$ Rox 500 GeneScan, and formamide at $94.2 \%$. This was denatured at $95^{\circ} \mathrm{C}$ for $5 \mathrm{~min}$ and submitted to capillary electrophoresis in an automatic sequencer ABI 3100.

\section{Statistical analyses}

For diversity analysis among the accessions based on qualitative traits, we used the mean Euclidean distance, expressed in Equation 1:

$$
d_{i j}=\sqrt{\frac{b+c}{a+b+c+d}}
$$

where $d_{i j}$ is the distance between the accessions $\mathrm{i}$ and $\mathrm{j} ; a$ is the coincidence number 1-1 type

Genetics and Molecular Research 16 (1): gmr16019590 
(Equation 3)

L.P. de Carvalho et al.

for each pair of accessions; $b$ is the discordance number 1-0 type for each pair of genotypes; $c$ is the discordance number 0-1 type for each pair of genotypes; $d$ is the coincidence number 0-0 type for each pair of genotypes.

For the analysis of diversity among the accessions based on the quantitative traits, we used the mean Euclidean distance, expressed in Equation 2:

$$
d_{i j}=\sqrt{\frac{\sum_{k=1}^{n}\left(Y_{i k}-Y_{j k}\right)^{2}}{n}}
$$

where $d_{i j}$ is the distance between the accessions $\mathrm{i}$ and $\mathrm{j} ; Y_{i k}$ is the observation in the access $\mathrm{i}$ in relation to k-th trait; $Y_{j k}$ is the observation in the access $\mathrm{j}$ in relation to $\mathrm{k}$-th trait.

For the joint analysis of the qualitative and quantitative traits, we used the Gower (1971) algorithm, according to Equation 3:

$$
S_{i j}=\frac{\sum_{k=1}^{n} W_{i j k} S_{i j k}}{\sum_{k=1}^{n} W_{i j k}}
$$

where $S_{i j}$ is the distance between the accessions i and $\mathrm{j} ; W_{i j k}$ is a weight given the comparison ijk, assigning 1 value for valid comparisons and 0 for invalid comparisons (when the trait value is absent in one or both accessions); $S_{i j k}$ is the contribution of the trait k in the similarity between the accessions $i$ and $\mathrm{j}$, having values between 0 and 1 .

In all cases, we used UPGMA (unweighted pair group method with arithmetic mean) cluster method (Sokal and Rohlf, 1962). All analyzes were performed with Genes software (Cruz, 2013).

\section{RESULTS AND DISCUSSION}

Although the cultivars studied here may not be those currently grown in Brazil and/or in their regions of origin, knowing the genetic diversity between different long and extra-long fiber genotypes is important for breeding programs, since they allow to direct crosses aiming increasing the fiber length.

\section{Diversity as to qualitative traits}

For CIR 246 marker, the control (Delta Opal) and genotypes Pima 6A, Pima S7, TAM 980-99 ne, and SUPIMA-RS-4 amplified a 146-bp band, associated with the bacterial blight resistance gene, B12 (Xiao et al., 2010) as can be seen in Table 1. Three accessions (Giza 59, Tanguis CN REG 701, and PI 635 119) were heterozygous but resistant showing the 146/156 or 146/166 band pattern. The other accessions (156 or 166 band pattern) were susceptible to this disease (Table 1).

From the accessions tested, 14 (Pima unknown, Pima S6, Giza 59, Giza 76, Giza 77, Giza 70, Giza 45, Giza 31, Giza 69, Giza 79, Tanguis LMG 1-72, Tanguis CN REG 701, Tanguis UNA 70-248, and Acala SJ5) amplified a 202-bp band for DC 20027 marker (Table 1). This band pattern is associated with a blue disease resistance gene (Fang et al., 2010). The other accessions presented a 200-bp band, being considered susceptible.

Genetics and Molecular Research 16 (1): gmr16019590 
Table 1. Means of qualitative traits resistant to bacterial blight (Bact), blue disease (Blue), and root-knot nematode (Nem) evaluated in 29 cotton accessions.

\begin{tabular}{|c|c|c|c|c|}
\hline Identification & Genotype & Bact & Blue & Nem \\
\hline G1 & Pima unknown & $\mathrm{S}$ & $\mathrm{R}$ & $\mathrm{R}$ \\
\hline G2 & Pima 6A & $\mathrm{R}$ & $\mathrm{S}$ & $\mathrm{R}$ \\
\hline G3 & Pima S7 & $\mathrm{R}$ & $\mathrm{S}$ & $\mathrm{R}$ \\
\hline G4 & Pima S6 & $\mathrm{S}$ & $\mathrm{R}$ & $\mathrm{R}$ \\
\hline G5 & Pima S4 & $\mathrm{S}$ & $\mathrm{S}$ & $\mathrm{R}$ \\
\hline G6 & Giza 59 & $\mathrm{R}^{\mathrm{a}}$ & $\mathrm{R}$ & $\mathrm{S}$ \\
\hline G7 & Giza 76 & $\mathrm{~S}$ & $\mathrm{R}$ & $\mathrm{S}$ \\
\hline G8 & Giza 77 & $\mathrm{~S}$ & $\mathrm{R}$ & $\mathrm{R}$ \\
\hline G9 & Giza 70 & $\mathrm{~S}$ & $\mathrm{R}$ & $\mathrm{R}$ \\
\hline G10 & Giza 45 & $\mathrm{~S}$ & $\mathrm{R}$ & $\mathrm{S}$ \\
\hline G11 & Giza 47 & $\mathrm{~S}$ & $\mathrm{~S}$ & $\mathrm{~S}$ \\
\hline G12 & Giza 31 & $\mathrm{~S}$ & $\mathrm{R}$ & $\mathrm{R}$ \\
\hline G13 & Giza 69 & $\mathrm{~S}$ & $\mathrm{R}$ & $\mathrm{R}^{\mathrm{a}}$ \\
\hline G14 & Giza 79 & $\mathrm{~S}$ & $\mathrm{R}$ & $\mathrm{S}$ \\
\hline G15 & Tanguis LMG 1-72 & $\mathrm{S}$ & $\mathrm{R}$ & $\mathrm{R}$ \\
\hline G16 & Tanguis HV-125 & $\mathrm{S}$ & $\mathrm{S}$ & $\mathrm{S}$ \\
\hline G17 & Tanguis CN REG 643 & $\mathrm{~S}$ & $\mathrm{~S}$ & $\mathrm{R}^{\mathrm{a}}$ \\
\hline G18 & Tanguis $1-805 \mathrm{~W}-63$ & $\mathrm{~S}$ & $\mathrm{~S}$ & $\mathrm{~S}$ \\
\hline G19 & Tanguis CN REG 701 & $\mathrm{R}^{\mathrm{a}}$ & $\mathrm{R}$ & $\mathrm{S}$ \\
\hline G20 & Tanguis UNA $70-248$ & $\mathrm{~S}$ & $\mathrm{R}$ & $\mathrm{S}$ \\
\hline G21 & Pima $1 \mathrm{AR}$ & $\mathrm{S}$ & $\mathrm{S}$ & $\mathrm{S}$ \\
\hline G22 & Pima 432-70 & $\mathrm{S}$ & $\mathrm{S}$ & $\mathrm{S}$ \\
\hline G23 & Acala SJ2 & $\mathrm{S}$ & $\mathrm{S}$ & $\mathrm{S}$ \\
\hline G24 & Acala SJ5 & $\mathrm{S}$ & $\mathrm{R}$ & $\mathrm{S}$ \\
\hline G25 & PI 528730 & $\mathrm{~S}$ & S & $\mathrm{S}$ \\
\hline G26 & PI 528727 & $\mathrm{~S}$ & $\mathrm{~S}$ & $\mathrm{~S}$ \\
\hline G27 & PI 635119 & $\mathrm{R}^{\mathrm{a}}$ & $\mathrm{S}$ & $\mathrm{S}$ \\
\hline$\overline{\mathrm{G} 28}$ & TAM 98D-99 ne & $\mathrm{R}$ & $\mathrm{S}$ & $\mathrm{S}$ \\
\hline G29 & SUPIMA-RS-4 & $\mathrm{R}$ & $\mathrm{S}$ & $\mathrm{S}$ \\
\hline
\end{tabular}

R: resistant; S: susceptible; aheterozygous.

For the BNL 3661 marker, eight accessions (Pima unknown, Pima 6A, Pima S7, Pima S6, Pima S4, Giza 77, Giza 70 and Giza 31,) amplified the 185/189 pattern band, associated with the presence of the resistance gene in G. hirsutum (Gutiérrez et al., 2010). Two accessions (Giza 69 and Tanguis CN REG 643) were heterozygous and resistant to this locus and presented $185 / 191$ band pattern, the others being susceptible.

The group I met all accessions susceptible to bacterial blight (Figure 1) and resistant to root-knot nematodes. However, the genotypes Pima unknown (G1), Pima S6 (G4), Giza 77 (G8), Giza 70 (G9), Giza 31 (G12), Giza 69 (G13), and Tanguis LMG 1-72 (G15) are resistant to blue disease, while genotypes Pima S4 (G5) and Tanguis CN REG 643 (G17) are susceptible. Group II contains the accessions resistant to bacterial blight and susceptible to blue disease, Pima 6A (G2) and Pima S7 (G3) are also resistant to root-knot nematode, while the other accessions of this group are susceptible. Accessions susceptible to root-knot nematode have formed Group III, but Giza 59 (G6) and Tanguis CN REG 701 (G19) are resistant to bacterial blight and blue disease.

These results indicate that complex crosses should be performed to result in a cotton genotype that simultaneously meets resistance to blue disease, bacteriosis and rootknot nematode. However, some strategies can be highlighted, such as crosses involving the genotypes Giza 59 (G6) and Tanguis CN REG 701 (G19) (resistant to bacterial blight and blue disease) with accessions allocated to Group I, which are resistant to root-knot nematode.

Genetics and Molecular Research 16 (1): gmr16019590 


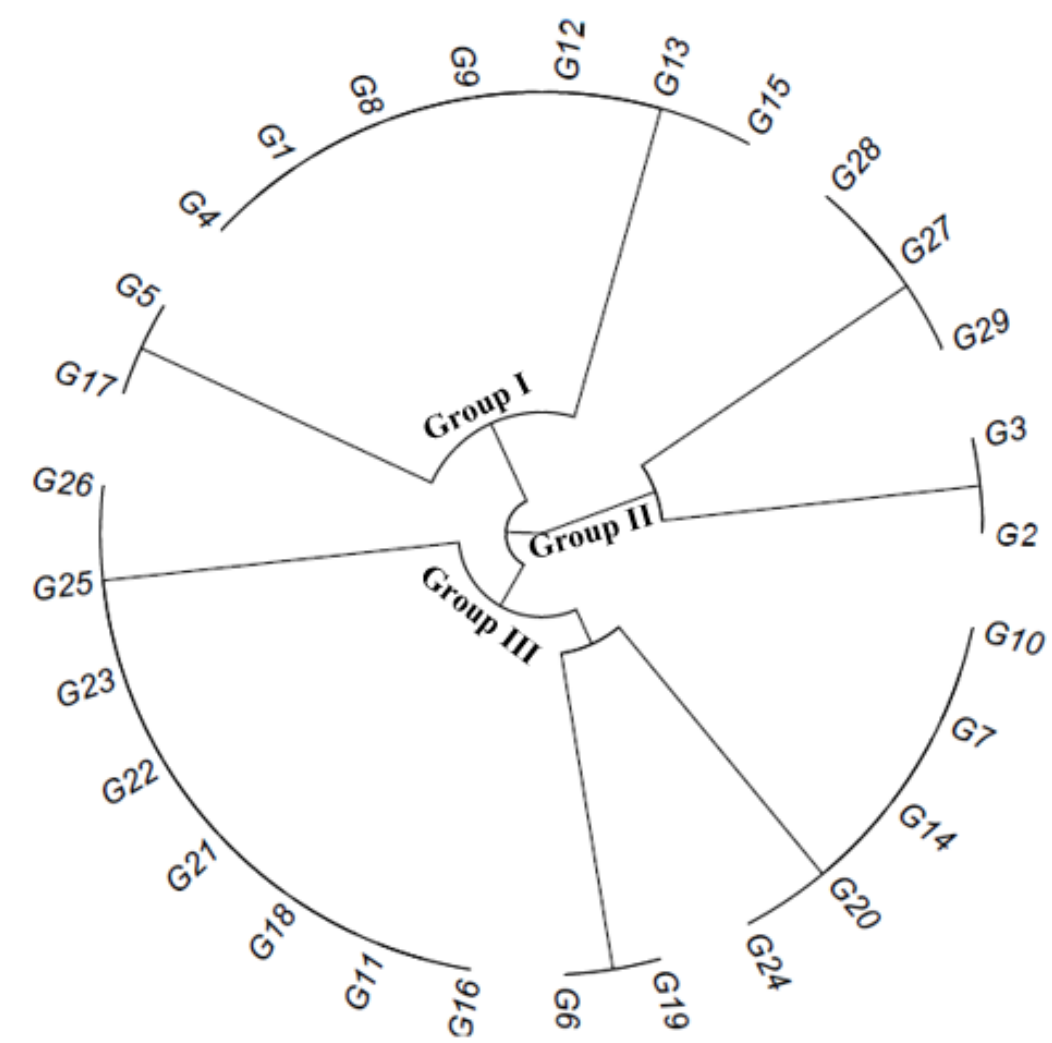

Figure 1. Cluster of 29 cotton accessions based on the mean Euclidean distance of the qualitative traits evaluated.

Genotypes arising from these crosses gather resistance to blue disease, bacterial blight and partial resistance to root-knot nematodes and can be used as parent donor of alleles in a recurrent selection program.

\section{Diversity as the quantitative traits}

Table 2 contains the means of the quantitative traits evaluated, where it is possible to highlight the access Pima S7 (G3) by the high fiber length (UHML) and reduced size. Increasing the fiber length trait is one of the main objectives of cotton-breeding programs. Additionally, genotypes with smaller size are desirable because they reduce losses from lodging and kneading during mechanical harvesting. Therefore, the use of this genotype in cross blocks can be promising to generate the segregating populations.

It is possible to verify in Figure 2 that the genetic diversity between accessions based only on the quantitative traits evaluated was narrow and limited, bringing them together in only two groups. Only the accessions Giza 79 (G14) and TAM 980-99 ne (G28) differed from the others, being allocated in Group II. These results suggest that these accessions can be used in crosses involving accessions from Group I to generate segregating populations with high genetic variability.

Genetics and Molecular Research 16 (1): gmr16019590 
Table 2. Mean of quantitative traits for the emergence of the first flower.

\begin{tabular}{|c|c|c|c|c|c|c|c|c|c|c|c|c|c|}
\hline Genotype & $\mathrm{PH}$ & $\mathrm{PF}$ & BW & LF & UNIF & SFI & FS & ST & MIC & MAT & REF & $+\mathrm{b}$ & SPI \\
\hline Pima S8 & 1.1 & 35.7 & 3.5 & 34.6 & 88.2 & 5.5 & 38.1 & 4.7 & 4.1 & 0.9 & 71.8 & 11.8 & 3959 \\
\hline Pima 6A & 1.9 & 31.4 & 4.3 & 38.5 & 90.5 & 5.5 & 36.1 & 5.0 & 3.6 & 0.9 & 77.6 & 8.7 & 4388 \\
\hline Pima S7 & 1.4 & 31.3 & 4.0 & 37.6 & 87.9 & 5.5 & 31.4 & 5.7 & 3.6 & 0.9 & 72.7 & 11.9 & 3804 \\
\hline Pima S6 & 1.2 & 36.0 & 3.8 & 33.6 & 87.5 & 5.6 & 37.2 & 5.8 & 4.5 & 0.9 & 71.0 & 12.1 & 3695 \\
\hline Pima S4 & 1.2 & 36.9 & 4.2 & 34.8 & 87.6 & 5.5 & 36.0 & 6.1 & 3.7 & 0.9 & 73.3 & 10.9 & 3857 \\
\hline Giza 59 & 1.8 & 33.3 & 3.6 & 36.9 & 88.4 & 5.5 & 33.3 & 4.2 & 3.5 & 0.9 & 73.5 & 10.1 & 3949 \\
\hline Giza 76 & 2.0 & 35.3 & 3.4 & 36.3 & 89.8 & 5.5 & 42.2 & 4.9 & 4.2 & 0.9 & 81.1 & 7.3 & 4494 \\
\hline Giza 77 & 1.5 & 37.3 & 3.4 & 34.0 & 88.5 & 5.5 & 40.6 & 4.8 & 4.2 & 0.9 & 68.8 & 11.3 & 4081 \\
\hline Giza 70 & 1.8 & 35.4 & 3.3 & 35.9 & 85.4 & 5.5 & 37.9 & 4.2 & 4.4 & 0.9 & 72.5 & 9.9 & 3660 \\
\hline GIZA 45 & 1.6 & 30.0 & 3.0 & 36.6 & 88.2 & 5.5 & 35.4 & 6.0 & 3.6 & 0.9 & 70.1 & 12.3 & 4003 \\
\hline GIZA 47 & 1.6 & 32.3 & 3.3 & 33.7 & 85.9 & 5.6 & 34.8 & 6.7 & 4.3 & 0.9 & 75.6 & 9.9 & 3438 \\
\hline Giza 31 & 1.8 & 35.1 & 3.7 & 25.3 & 81.5 & 7.8 & 33.1 & 10.2 & 5.4 & 0.9 & 63.3 & 13.5 & 2186 \\
\hline Giza 69 & 2.0 & 37.5 & 3.2 & 33.2 & 88.5 & 5.7 & 37.8 & 6.1 & 5.0 & 0.9 & 82.9 & 6.6 & 3704 \\
\hline GIZA 79 & 2.1 & 38.6 & 3.5 & 33.7 & 87.8 & 5.6 & 34.7 & 6.4 & 4.6 & 0.9 & 67.9 & 12.6 & 3562 \\
\hline Tanguis LMG 1-72 & 2.4 & 34.6 & 4.1 & 33.9 & 87.6 & 5.5 & 33.4 & 6.0 & 5.8 & 0.9 & 81.8 & 7.3 & 3220 \\
\hline Tanguis HV-125 & 2.4 & 34.6 & 2.6 & 33.3 & 84.5 & 5.7 & 36.1 & 5.8 & 5.2 & 0.9 & 83.5 & 7.2 & 3141 \\
\hline Tanguis CN REG 643 & 1.9 & 32.4 & 3.6 & 36.6 & 88.1 & 5.5 & 31.1 & 5.1 & 3.6 & 0.9 & 72.1 & 12.0 & 3748 \\
\hline Tanguis $1-805 \mathrm{~W}-63$ & 2.6 & 36.0 & 4.5 & 31.5 & 86.4 & 6.1 & 36.0 & 8.2 & 5.4 & 0.9 & 83.3 & 8.4 & 3200 \\
\hline TanguiS CN REG 701 & 1.5 & 33.3 & 3.2 & 33.7 & 82.6 & 5.6 & 32.1 & 5.5 & 4.2 & 0.9 & 82.1 & 7.1 & 2949 \\
\hline Tanguis UNA 70-248 & 1.8 & 37.2 & 3.9 & 33.2 & 87.5 & 5.7 & 41.4 & 4.8 & 4.9 & 0.9 & 84.4 & 7.1 & 3822 \\
\hline Pima 1AR & 2.2 & 31.0 & 4.4 & 37.9 & 87.8 & 5.5 & 31.8 & 4.3 & 3.6 & 0.9 & 76.6 & 10.2 & 3824 \\
\hline Pima 432-70 & 1.8 & 31.8 & 4.4 & 37.2 & 87.0 & 5.5 & 37.0 & 4.8 & 3.8 & 0.9 & 77.8 & 9.1 & 3976 \\
\hline Acala SJ2 & 0.9 & 37.8 & 6.0 & 31.1 & 86.7 & 6.0 & 31.4 & 5.7 & 4.3 & 0.9 & 82.3 & 8.3 & 3178 \\
\hline Acala SJ5 & 1.4 & 29.2 & 6.5 & 32.8 & 87.7 & 5.7 & 30.1 & 4.3 & 4.2 & 0.9 & 85.2 & 5.7 & 3314 \\
\hline PI 528730 & 1.2 & 38.1 & 7.0 & 30.3 & 87.0 & 6.3 & 29.8 & 5.7 & 4.3 & 0.9 & 82.5 & 7.5 & 3075 \\
\hline PI 528727 & 0.9 & 38.6 & 6.4 & 30.3 & 84.2 & 6.9 & 27.6 & 6.0 & 4.5 & 0.9 & 80.6 & 7.8 & 2611 \\
\hline PI 635119 & 1.2 & 40.8 & 6.0 & 30.1 & 87.5 & 5.8 & 32.1 & 4.9 & 4.4 & 0.9 & 82.9 & 7.0 & 3229 \\
\hline TAM 98D-99 ne & 1.0 & 40.3 & 6.0 & 29.2 & 85.6 & 6.2 & 34.1 & 5.4 & 4.6 & 0.9 & 81.4 & 8.1 & 3049 \\
\hline SUPIMA-RS-4 & 2.1 & 33.7 & 4.5 & 36.4 & 87.1 & 5.5 & 35.3 & 5.4 & 3.6 & 0.9 & 77.4 & 9.5 & 3887 \\
\hline
\end{tabular}

Plant height (PH), percentage of fibers (PF), boll weight (BW), length of fibers (LF), fiber uniformity (UNIF), short fiber index (SFI), fiber strength (FS), stretching (ST), micronaire (MIC), fiber maturity (MAT), reflectance (REF), yellowing degree $(+b)$, and spinning (SPI) evaluated in 29 cotton accessions.

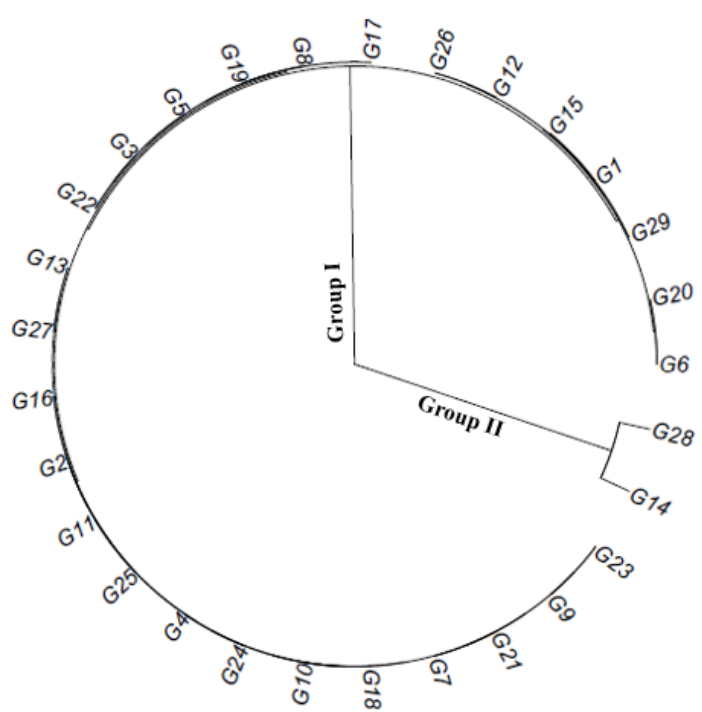

Figure 2. Cluster of 29 cotton accessions based on the mean Euclidean distance of the quantitative traits evaluated.

Genetics and Molecular Research 16 (1): gmr16019590 


\section{Diversity as the qualitative and quantitative traits simultaneously}

Using the Gower algorithm to joint analysis of the quantitative and qualitative traits, we verified an increase in the genetic distance among the accessions evaluated (Figure 3). The most research on germplasm characterization and evaluation, in general, uses qualitative and quantitative traits separately, since the latter are analyzed only by descriptive statistics. This may segment the inferences and conclusions about genetic divergence among genotypes, often limiting their subsequent use, for example, in breeding programs (Cruz et al., 2011). These results demonstrate that when the breeder has evaluation information about qualitative and quantitative traits, they should not be analyzed singly. Other researchers who used the Gower (1971) algorithm for studying diversity in Uruchloa brizantha (Torres et al., 2015) and tomato (Rocha et al., 2010; Moura et al., 2010) reported similar results.

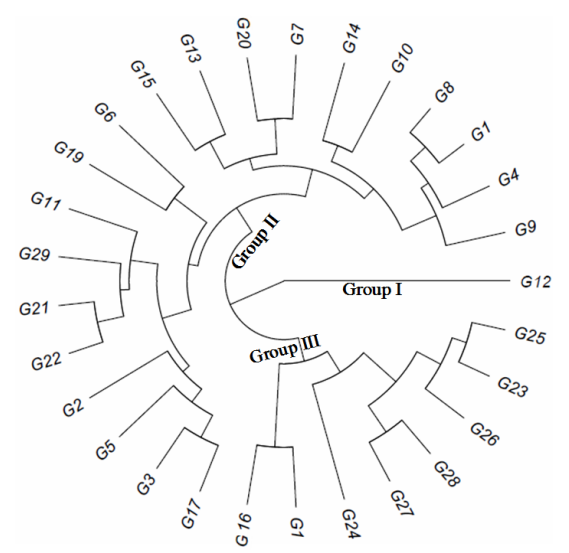

Figure 3. Cluster of 29 cotton accessions based on the calculated Gower distance based on qualitative and quantitative traits.

From the distance of Gower, we verified the inclusion of the accessions in three distinct groups. It is noted from Figure 3 that ELS cotton genotypes with length of fibers $\geq 32 \mathrm{~mm}$ and others with medium-fiber (PI 528727, PI 635 119, PI 528730, TAM 980-99ne, ACALA SJ2, and ACALA SJ5) formed a distinct group from the other genotypes, which are pure $G$. barbadense (Giza, Tanguis, and Pima). G. barbadense genotypes had length of fiber ranging from 33.2 to $38.5 \mathrm{~mm}$ (Table 2), with the exception of Giza 31 and Tanguis 1-80 5W-63. Fiber of genotypes Acala SJ2 and Acala SJ 5 had length 31.1 and $32.8 \mathrm{~mm}$, respectively, two obsolete cultivars released in the 1970's (Smith and Cothren, 1999). These authors comment that in the formation of populations, for obtaining these materials there was introgression of $G$. barbadense genes. Most of the cultivars Pima and Giza constituted a group, but among them, there are distances smaller than between ELS upland.

PI 528727 and PI 528730 accessions, although they are related to extra-long length in the literature and having G. barbadense in their pedigree (Smith et al., 2008), both presented in this study a length of $30.3 \mathrm{~mm}$. The access TAM 98D-99e is from G. hirsutum L. and was developed in a breeding program aiming at yield potential and fiber quality (Thaxton and Smith, 2005). The access PI 635119 combines high-yield potential and good fiber qualities (May et al., 2005). The results of this study show the influence of fiber length on the divergence and

Genetics and Molecular Research 16 (1): gmr16019590 
cluster of genotypes. Giza 31 obtained the lowest length of fiber $(25.3 \mathrm{~mm})$, being considered short fiber and formed alone the Group I. Group II allocated the medium-fiber genotypes and those with introgression of G. barbadense. Group III added materials with extra-long fiber of pure G. barbadense (Pima, Giza, and Tanguis).

According to Smith and Cothren (1999) most efforts to attain better fiber traits in upland cotton to reach the same elite quality of Pima have been through hybridization of G. hirsutum L. and G. barbadense L. but with little success. Therefore, it is important to know the main phenotypic traits of the main long and extra-long fiber materials and their genetic divergence before using them in breeding programs. Moreover, these results are important for formatting populations with high variability, especially for resistance to diseases and nematode, since according to Gutiérrez et al. (2010), when cotton parents are contrasting in agronomic and fiber traits, there is efficiency in predicting F2 generation performance. Based on the cluster of genotypes as quantitative and qualitative traits, the most promising combination to generate segregating populations resistant to blue disease and bacterial blight, partial resistance to root-knot nematode, smaller size, and good fiber characteristics is the cross between the accessions Giza 59 (G6) and Pima unknown (G1).

\section{CONCLUSIONS}

The genotypes were grouped according to the greater or lesser length of fibers. The cross between the accessions Giza 59 and Pima unknown is the most promising combination to generate segregating populations resistant to blue disease and bacterial blight, partial resistance to root-knot nematode, smaller size, and good fiber characteristics. The genotypes of these segregating populations may be used in recurrent selection programs as donors of alleles for Brazilian genotypes.

\section{Conflicts of interest}

The authors declare no conflict of interest.

\section{ACKNOWLEDGMENTS}

We thank Coordenação de Aperfeiçoamento de Pessoal de Nível Superior (CAPES) and Conselho Nacional de Desenvolvimento Científico e Tecnológico (CNPq) for financial support.

\section{REFERENCES}

Carvalho LP, Lanza MA, Fallieri J and Santos JW (2003). Análise da diversidade genética entre acessos de banco ativo de germoplasma de algodão. Pesqui. Agropecu. Bras. 38: 1149-1155. http://dx.doi.org/10.1590/S0100204X2003001000003

Cruz CD (2013). GENES - a software package for analysis in experimental statistics and quantitative genetics. Acta Sci. Agron. 35: 271-276. http://dx.doi.org/10.4025/actasciagron.v35i3.21251

Cruz CD, Ferreira FM and Pessoni LA (2011). Biometria aplicada ao estudo da diversidade genética. Visconde do Rio Branco: Suprema.

Fang DD, Xiao J, Canci PC and Cantrell RG (2010). A new SNP haplotype associated with blue disease resistance gene in cotton (Gossypium hirsutum L.). Theor. Appl. Genet. 120: 943-953. http://dx.doi.org/10.1007/s00122-009-1223-y

Farias FJC, Carvalho LP, Silva Filho JL and Teodoro PE (2016). Biplot analysis of phenotypic stability in upland cotton genotypes in Mato Grosso. Genet. Mol. Res. 15: http://dx.doi.org/10.4238/gmr.15028009.

Genetics and Molecular Research 16 (1): gmr16019590 
Gower JC (1971). A general coefficient of similarity and some of its properties. Biometrics 27: 857-874. http://dx.doi. org $/ 10.2307 / 2528823$

Gutiérrez OA, Jenkins JN, McCarty JC, Wubben MJ, et al. (2010). SSR markers closely associated with genes for resistance to root-knot nematode on chromosomes 11 and 14 of Upland cotton. Theor. Appl. Genet. 121: 1323-1337. http://dx.doi.org/10.1007/s00122-010-1391-9

Hoogerheide ESS, Vencovsky R, Farias FJC, Freire EC, et al. (2007). Correlações e análise de trilha de caracteres tecnológicos e produtividade de fibra de algodão. Pesqui. Agropecu. Bras. 42: 1401-1405. http://dx.doi.org/10.1590/ $\underline{\mathrm{S} 0100-204 X 2007001000005}$

May OL, Cantrell RG and Jones DC (2005). GA98066 Upland Cotton Germplasm Line. Crop Sci. 45: 1175-1176. http:// dx.doi.org/10.2135/cropsci2004.0556GP

Morello CL, Pedrosa MB, Suassuna ND, Lamas FM, et al. (2012). BRS 336: a high-quality fiber upland cotton cultivar for Brazilian savanna and semi-arid conditions. Crop Breed. Appl. Biotechnol. 12: 92-95. http://dx.doi.org/10.1590/ $\underline{\text { S1984-70332012000100012 }}$

Moura MCCL, Leandro SA, Sudré CP, Rodrigues R Amaral Júnior, et al. (2010). Algoritmo de Gower na estimativa da divergência genética em germoplasma de pimenta. Hortic. Bras. 28: 155-161. http://dx.doi.org/10.1590/S010205362010000200003

Rocha MC, Gonçalves LSA, Rodrigues R, Silva PRA, et al. (2010). Uso do algoritmo de Gower na determinação da divergência genética entre acessos de tomateiro do grupo cereja. Acta Sci. Agron. 32: 423-431. http://dx.doi. org/10.4025/actasciagron.v32i3.4888

Sokal RR and Rohlf FJ (1962). The comparison of dendrograms by objective methods. Taxon 11: 33-40. http://dx.doi. org $/ 10.2307 / 1217208$

Smith CW and Cothren JT (1999). Cotton: origin, history, technology and production. Madson: Wiley Series in Crop Science.

Smith CW, Hague S, Hequet E, Thaxton S, et al. (2008). Development of extra-long staple upland cotton. Crop Sci. 48: 1823-1832. http://dx.doi.org/10.2135/cropsci2008.01.0052

Thaxton PM and Smith CW (2005). Cantrel, R, TAM 98D-102 and TAM 98D-99ne Upland cotton germplasm Lines with high Strength. Crop Sci. 45: 1668-1669. http://dx.doi.org/10.2135/cropsci2004.0629

Torres FE, Valle CB, Lempp B, Teodoro PE, et al. (2015). Estimativa da divergência entre ecótipos de braquiária baseada em descritores quantitativos e qualitativos. Cienc. Rural 45: 485-491. http://dx.doi.org/10.1590/0103-8478cr20140537

Xiao J, Fang DD, Bhatti M, Hendrix B, et al. (2010). A SNP haplotype associated with a gene resistant to Xanthomonas axonopodis pv. malvacearum in upland cotton (Gossypium hirsutum L.). Mol. Breed. 25: 593-602. http://dx.doi. org $/ 10.1007 / \mathrm{s} 11032-009-9355-\mathrm{y}$

Genetics and Molecular Research 16 (1): gmr16019590 